\title{
Quarterly Progress Report \\ Covering Period April 2 \\ Through June 29, 1979- \\ The Study of Plutonium Oxide \\ Leak Rates from Shipping \\ Containers
}

July 1979

Prepared for

the U.S. Nuclear Regulatory Commission

under a Related Services Agreement with the U.S. Department of Energy

Contract EY-76-C-06-1830

Pacific Northwest Laboratory

Operated for the U.S. Department of Energy

by Battelle Memorial Institute 


\section{NOTICE}

This report was prepared as an account of work sponsored by the United States Government. Neither the United States nor the United States Nuclear Regulatory Commission, nor any of their employees, nor any of their contractors, subcontractors, or their employees, makes any warranty, express or implied, or assumes any iegal liability or responsibility for the accuracy, completeness or useiuiness of anv intormation, apparatus, product or process disclosed, or represents that its use would not infringe privately owned rights.

PACIFIC NORTHWEST LABORATORY

operated by

BATTELLE

for the

UNITED STATES DEPARTMENT GF ENERGY

Under Contract EY-76-C-06-1830 


\title{
33679000518045
}

Accession No.

PNL-2260-11

\section{INTERIM REPORT}

CONTRACT PROGRAM OR PROJECT TITLE; PuO2 Particle Leak Studies

SUBJECT OF THIS DOCUMENT: QUARTERLY PROGRESS REPORT COVERING PERIOD

APRIL 2 THROUGH JUNE 29, 1979 - THE STUDY

OF PLUTONIUM OXIDE LEAK RATES FROM SHIPPING CONTAINERS

AUTHORS(S): L. C. Schwendiman, W. J. Madia, J. Mishima, S. L. Sutter,

P. C. Owzarski, T. J. Bander, E. W. Schmidt and J. D. Yesso

TYPE OF REPORT: Status Summary Report

DATE OF DOCUMENT: JuTy 1979

RESPONSIBLE NRC INDIVIDUAL AND NRC OFFICE OR DIVISION:

William R. Lahs

Systems Performance Branch

Div. of Safeguards, Fuel Cycle \& Environmental Research

This document was prepared primarily for preliminary or internal use. It has not received full review and approval. Since there may be substantive changes, this document should not be considered final.

\author{
PACIFIC NORTHWEST LABORATORY \\ Operated by \\ BATTELLE MEMORIAL INSTITUTE \\ for the \\ UNITED STATES DEPARTMENT OF ENERGY \\ Prepared for \\ U.S. Nuclear Regulatory Commission \\ Washington, DC 20555 \\ Under Interagency Agreement \\ EY-76-C-06-1830 \\ NRC FIN No. B2093
}

INTERIM REPORT 
TABLE OF CONTENTS

Page

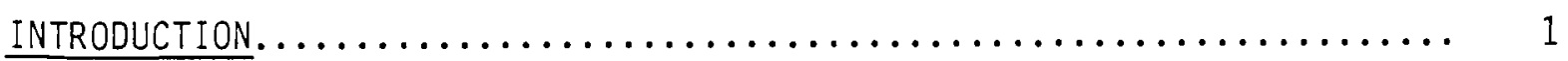

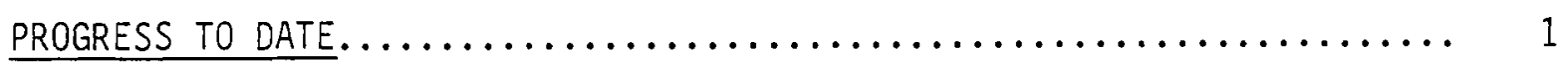

TASK A -- Review literature and theoretical work relating to transmission of particles through channels........... 1

TASK B -- Investigate the relationship of gas flow rates, leak geometries, pressure and temperatures............. 1

TASK C -- Measure transmission of a well-characterized simulant $\left(\mathrm{UO}_{2}\right.$ powder) through leaks characterized in Task $\mathrm{B} . . . .2$

TASK D -- Measure fuel grade $\mathrm{PuO}_{2}$ leaks through a "standard leak" incorporated into a suitable container.......... 3

TASK E -- Investigate $\mathrm{PuO}_{2}$ leaks through simulated defected containers............................... 11

TASK F -- Develop Analys is Methodology................. 12 

QUARTERLY PROGRESS REPORT

Apri1 2 - June 29, 1979

STUDY OF PLUTONIUM OXIDE LEAK RATES FROM SHIPPING CONTAINERS

INTRODUCTION

This study was initiated in October 1976, as outlined in the 189 research proposal submitted previously. Several tasks are to be undertaken in this study which, when combined, have the end objective of defining the leak rates of plutonium oxide powder from characterized leaks.

This is the eleventh, and final, quarterly report of this work. Previous reports were issued as BNWL-2260-1, -2, -3, -4, -5, -6, -7, -8, -9, and -10 . Each task will be identified and the progress during the reporting period briefly described.

PROGRESS TO DATE

IASK A -- Review literature and theoretical work relating to transmission of particles through channels

Task objective has been fulfilled, and two reports issued: Supporting Information for the Estimation of Plutonium Oxide Leak Rates Through Very Small Apertures, by L. C. Schwendiman, BNWL-2198; and Transport of Particles Through Gas Leaks -- A Review, by L. C. Schwendiman and S. L. Sutter, BNWL-2218, January 1977.

TASK B -- Investigate the relationship of gas flow rates, leak geometries, pressures and temperatures

Milestone 1. Review literature on topic.

Milestone 2. Report on technical literature.

These milestones were reached and a document, Estimation of Gas Leak Rates Through Very Small Orifices and Channels, by H. J. Bomelburg, BNWL-2223, was issued.

Milestone 3. Select method and design apparatus for flow experiments. Milestone 4. Fabricate and assemble apparatus. 
Milestone 5. Test apparatus.

Milestone 6 . Conduct first test.

Milestones 1 through 6 were completed in FY 1977.

Milestone 7. Complete test series (orifices). January 1978.

Milestone 8. Draft Report. March 1978.

Milestone 9. Issue report.

The document Measured Airflow Rates Through Micro-orifices and Flow Prediction Capability, NUREG/CR-0066 (PNL-2611), was issued in July 1978.

Milestone 10. Fabricate microcapillaries.

Milestone 11. Complete test series. April 1978.

Milestone 12. Draft report.

Measured and Predicted Gas Flow Rates Through Rough Capillaries, by P. C. Owzarski, S. L. Sutter, J. Mishima, L. C. Schwendiman and T. J. Bander, NUREG/CR-0745 (PNL-2623), Pacific Northwest Laboratory, Richland, WA, was issued in May, 1979. The document compares experimental flow data through 50to 250-micrometer-diameter metal capillaries, 0.76 to $2.54 \mathrm{~cm}$ long, with data generated by a computer model, Code CAPIL.

TASK C -- Measure transmission of a well-characterized simulant (UOO 2 powder) through leaks characterized in Task $B$

Milestone 1. Pressure vessel for simulating container available for experiments. June 1978.

Milestone 2. Convert airflow apparatus. Completed January 1978. Milestone 3. First experiment completed.

A11 experiments were completed in April 1979 and included in the last quarterly report (PNL-2260-10).

In addition, the length-to-diameter ( $L / D)$ ratio of the orifices has been investigated further. An L/D ratio of 1 or less had been specified for orificies in Measured Air Flow Rates Through Microorifices and Flow Prediction Capability, NUREG/CR-0066 PNL-2611, by S. L. Sutter, T. J. Bander, J. Mishima and L. C. Schwendiman, Pacific Northwest Laboratory, 1978. However, a nondestructive method to accurately measure the length of the orifice was not 
readily available. Use of the depth of focus of an optical microscope indicated that for one $20-\mu m$ or ifice the length of the or ifice could have been up to $193 \mathrm{\mu m}$. In the present investigation, one 20-um orifice was impregnated with resin, sectioned and measured after the powder leak experiments were completed. This single orifice had a leak path length of $560 \mu \mathrm{m}$, which would indicate an $L / D$ of 28 . This same path length would have an $L / D$ ratio of 2.8 in a $200-\mu \mathrm{m}$ orifice. Time and funding restraints precluded a comprehensive investigation of the leak path length problem.

Milestone 4. Draft Report.

Completion of the report was delayed, pending statistical. analys is of data and decisions pertaining to presentation of data. Questions related to these issues are being resolved and the document finalized.

TASK D -- Measure Fuel Grade PuO 2 Leaks Through a "Standard Leak" Incorporated into a Suitable Container

Milestone 1. Design of experimental equipment. Completed. Milestone 2. Assembly of experimental system. Completed. Milestone 3. Simulant experiments. Completed. Milestone 4. Transfer to glove box. Completed. Milestone 5. Conduct "hot" experiments. Completed.

Experiments Pu 119 through Pu $127 \mathrm{a}$ and $\mathrm{Pu} 130$ and $130 \mathrm{a}$ were conducted under conditions that duplicated those of experiments $\mathrm{Pu} 111$ through $\mathrm{Pu} 118 \mathrm{a}$ reported in the tenth quarterly report. Those past and present experiments were conducted with 50-4m orifices. However, shortly after the installation of the orifice used during runs Pu 111 through Pu 118a, the orifice appeared to become plugged as the helium leak drastically decreased, and the observed helium leak rates, as determined by the pressure decay method, were comparable

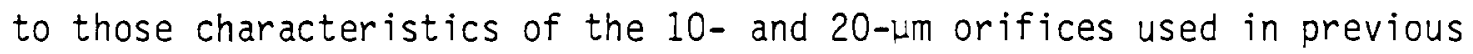
experiments. To allow comparisons to be made between these tenth quarteriy report experiments and the more recent 50- $\mu \mathrm{m}$ experiments (runs $\mathrm{Pu} 119$ through $\mathrm{Pu} 127 \mathrm{a}$ and $\mathrm{Pu} 130$ and $\mathrm{Pu} 130 \mathrm{a}$ ), the results of runs $\mathrm{Pu} 111$ through $\mathrm{Pu} 118 \mathrm{a}$ are presented in Figure 1 and Table I. As is apparent from inspection of these results, three quarters of the runs exhibited no net $\mathrm{PuO}_{2}$ emission. 


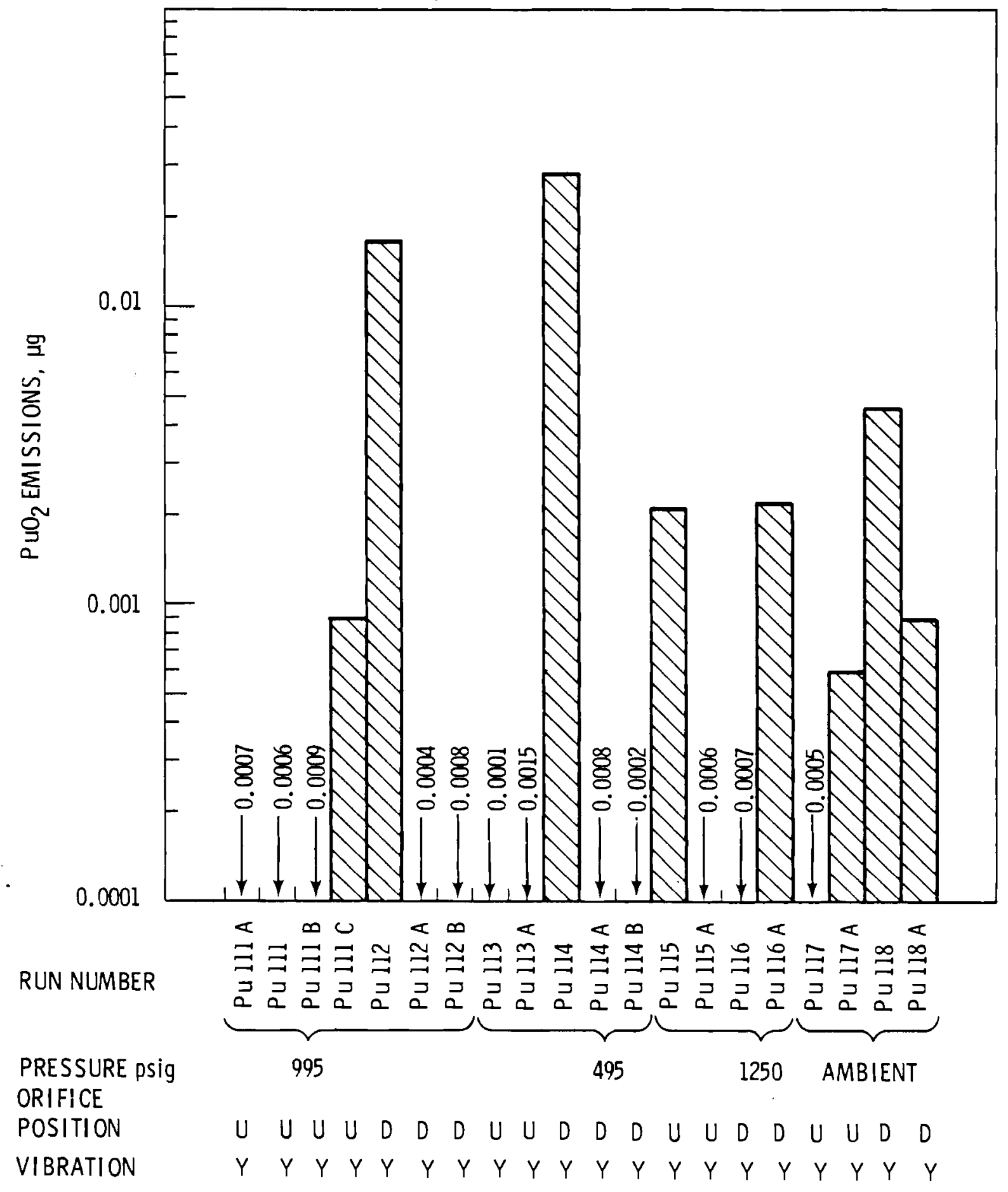

FIGURE 1. Effects of Experimental Conditions on $\mathrm{PuO}_{2}$
Emissions Through a $50-\mu \mathrm{m}$ Orifice 
TABLE I

SUMMARY OF PU0 2 LEAK RATE EXPERIMENTS USING A 50- 4 M ORIFICE

\begin{tabular}{|c|c|c|c|c|c|c|}
\hline \multirow[b]{2}{*}{$\begin{array}{l}\text { Run } \\
\text { Number }\end{array}$} & \multirow[b]{2}{*}{$\begin{array}{c}\text { Tube } \\
\text { Position }\end{array}$} & \multirow{2}{*}{$\begin{array}{c}\text { Helium } \\
\text { Pressure, } \\
\text { psig }\end{array}$} & \multirow[b]{2}{*}{ Vibration } & \multirow{2}{*}{$\begin{array}{l}\text { Helium } \\
\text { Leak } \\
\text { Rate(b) } \\
\text { scc/sec }\end{array}$} & \multicolumn{2}{|c|}{$\begin{array}{l}\text { Quantity of } \mathrm{PuO}_{2} \\
\text { Detected, } \mu \mathrm{g}(\mathrm{af}\end{array}$} \\
\hline & & & & & Total & $\begin{array}{l}\text { Net } \\
\text { Total }(c)\end{array}$ \\
\hline Pu 111 & Up & 1000 & Yes & 8.7 & 0.0006 & -0.0007 \\
\hline $\mathrm{Pu} 111 \mathrm{a}$ & Up & 1000 & Yes & 37.2 & 0.0007 & -0.0006 \\
\hline $\mathrm{Pu} 111 \mathrm{~b}$ & Up & 1000 & Yes & 2.6 & 0.0007 & -0.0009 \\
\hline $\mathrm{Pu} 111 \mathrm{c}$ & Up & 1000 & Yes & 3.5 & 0.0022 & 0.0009 \\
\hline Pu 112 & Down & 1000 & Yes & 2.6 & 0.0179 & 0.0166 \\
\hline $\mathrm{Pu} 112 \mathrm{a}$ & Down & 1000 & Yes & 3.5 & 0.0009 & -0.0004 \\
\hline $\mathrm{Pu} 112 \mathrm{~b}$ & Down & 1000 & Yes & 2.6 & 0.0005 & -0.0008 \\
\hline Pu 113 & Up & 500 & Yes & 1.3 & 0.0014 & 0.0001 \\
\hline Pu 113a & Up & 500 & Yes & 1.3 & -0.0002 & -0.0015 \\
\hline Pu 114 & Down & 500 & Yes & 1.3 & 0.0293 & 0.0280 \\
\hline Pu 114a & Down & 500 & Yes & 1.3 & 0.0005 & -0.0008 \\
\hline $\mathrm{Pu} 114 \mathrm{~b}$ & Down & 500 & Yes & 1.3 & 0.0011 & -0.0002 \\
\hline Pu 115 & Up & 1250 & Yes & 4.8 & 0.0034 & 0.0021 \\
\hline $\mathrm{Pu} 115 \mathrm{a}$ & Up & 1250 & Yes & 4.8 & 0.0007 & -0.0006 \\
\hline Pu 116 & Down & 1250 & Yes & 5.4 & 0.0006 & -0.0007 \\
\hline $\mathrm{Pu} 116 \mathrm{a}$ & Down & 1250 & Yes & 5.2 & 0.0035 & 0.0022 \\
\hline Pu 117 & Up & Ambient & Yes & - & 0.0008 & -0.0005 \\
\hline Pu 117a & Up & Ambient & Yes & - & 0.0019 & 0.0006 \\
\hline Pu 118 & Down & Ambient & Yes & - & 0.0059 & 0.0046 \\
\hline Pu 118a & Down & Ambient & Yes & - & 0.0022 & 0.0009 \\
\hline
\end{tabular}

(a) Based on a specific activity of $0.096 \mathrm{Ci} / \mathrm{g}$ for the $\mathrm{PuO}_{2}$ powder.

(b) Helium leak rate determined by the pressure decay method at the midpoint of the run.

(c) The net total amount above the average containment box background of $0.0013 \mu \mathrm{g}$. 
Spare 50-um or ifices were chemically cleaned and microscopically examined to insure that openings were unobstructed and of sizes comparable to the one used in the $\mathrm{Pu} 111$ through $\mathrm{Pu} 118 \mathrm{a}$ experiments. The results of experiments $\mathrm{Pu}$ 119 through 127 a are presented in Figure 2 and Table II. As is apparent from an examination of Table II, flow rates were not constant between runs, and a significant decrease was observed between runs $\mathrm{Pu} 120 \mathrm{a}$ and $\mathrm{Pu} 121$. It appears that some plugging of the or ifice may have occurred between those two runs with the orifice remaining plugged through run $\mathrm{Pu} 123$. Five of the six runs exhibited very low $\mathrm{PuO}_{2}$ emissions as might be expected for such low flows. The high emission of $\mathrm{PuO}_{2}$ observed for run $\mathrm{Pu} 121$ may be explained by assuming that the plugging may have occurred during the initial pressurization period when the flow cannot be determined but after the observed $\mathrm{PuO}_{2}$ was emitted. It should be noted that recordings of the helium flow rates during the course of the runs show only minor flow rate changes. This observation indicates that if, in fact, plugging or unplugging of the orifice is present, these plugging or unplugging conditions probably occur during the initial pressurization or depressurization of the leak tube.

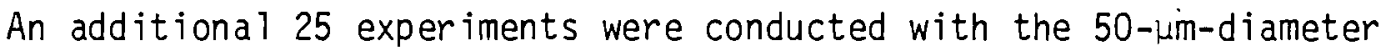
orifice. All of these runs were carried out with a helium pressure of 1000 psi. The results of these runs and the actual experimental conditions are presented in Table III and Figure 3. Experiments Pu 128 through 128d were "zero-time" runs, and Pu 129 through Pu 129d were 60-min runs; otherwise, the run conditions were identical. An inspection of these data reveals that there is no direct relationship between the run time and the total $\mathrm{PuO}_{2}$ emission, an observation verified by a statistical analysis that indicates that there is no significant difference between the two sets of data.

Runs Pu 131 through Pu 131n (also presented in Table III and Figure 3) were conducted under one set of conditions to allow the data to be examined for a correlation between the helium flow rate and the $\mathrm{PuO}_{2}$ emissions. No such direct correlation is apparent from a simple inspection of the data; however, the flow rate changes are small and the effects of such a change may not be noticeable. The data are currently being subjected to a more rigorous analysis. Another reason for running this series of experiments is that it 


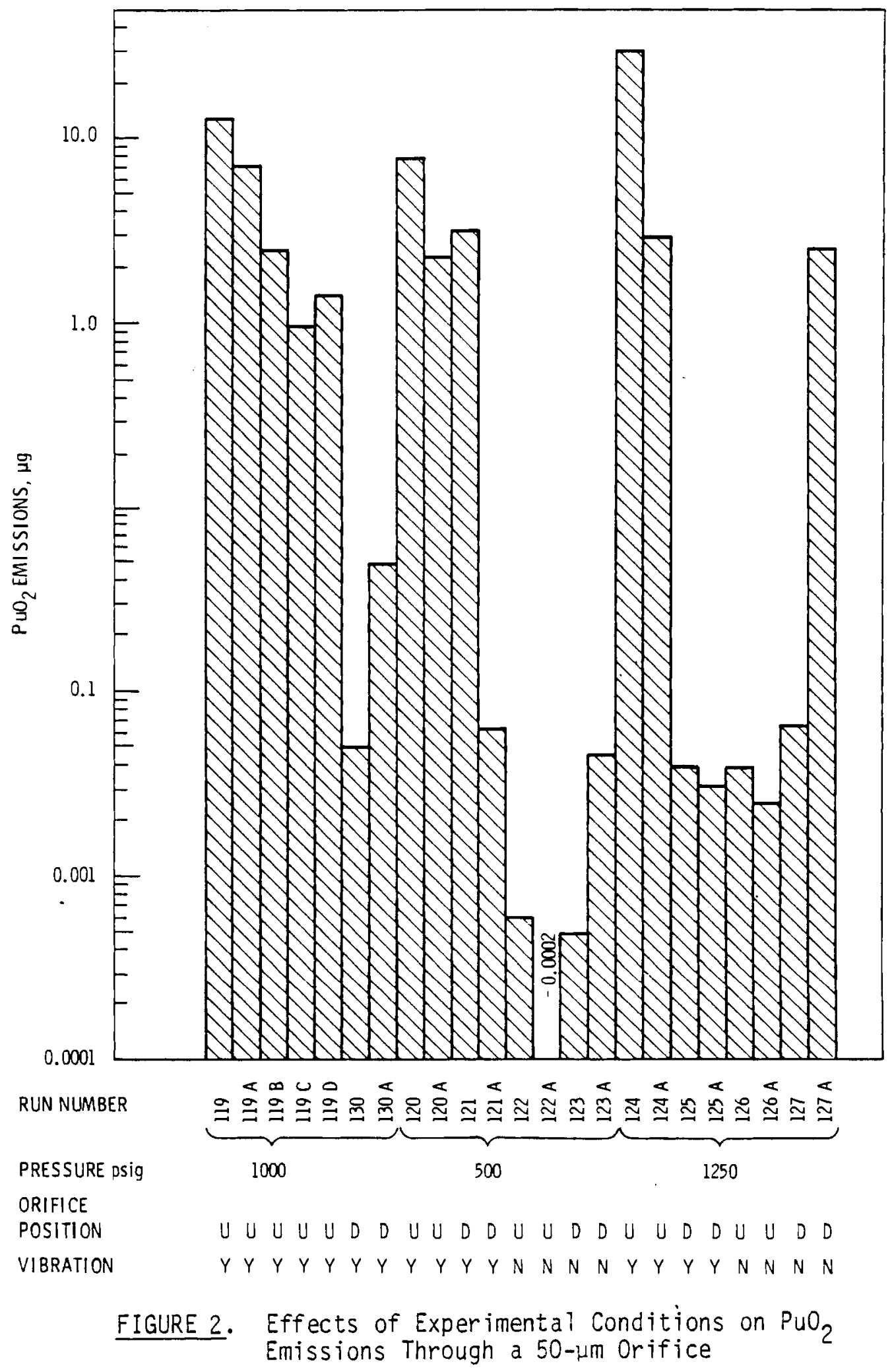


TABLE II

SUMMARY OF PU0 2 LEAK RATE EXPERIMENTS USING A 50- $\mu$ M ORIFICE

\begin{tabular}{|c|c|c|c|c|c|c|}
\hline \multirow[b]{2}{*}{$\begin{array}{l}\text { Run } \\
\text { Number }\end{array}$} & \multirow[b]{2}{*}{$\begin{array}{c}\text { Tube } \\
\text { Position }\end{array}$} & \multirow{2}{*}{$\begin{array}{c}\text { Helium } \\
\text { Pressure, } \\
\text { psig }\end{array}$} & \multirow[b]{2}{*}{ Vibration } & \multirow{2}{*}{$\begin{array}{l}\text { Helium } \\
\text { Leak } \\
\text { Rate(b) } \\
\mathrm{scc} / \mathrm{sec}\end{array}$} & \multicolumn{2}{|c|}{$\begin{array}{l}\text { Quantity of } \mathrm{PuO}_{2} \\
\text { Detected, } \mu \mathrm{g}(\mathrm{a})\end{array}$} \\
\hline & & & & & Total & $\begin{array}{l}\text { Net } \\
\text { Total (c) }\end{array}$ \\
\hline Pu 119 & Up & 1000 & Yes & 49.6 & 12.80 & 12.80 \\
\hline $\mathrm{Pu} 119 \mathrm{a}$ & Up & 1000 & Yes & 50.0 & 7.206 & 7.20 \\
\hline $\mathrm{Pu} 119 \mathrm{~b}$ & Up & 1000 & Yes & 50.0 & 2.4934 & 2.492 \\
\hline $\mathrm{Pu} 119 \mathrm{C}$ & Up & 1000 & Yes & 50.4 & 0.9838 & 0.9825 \\
\hline $\mathrm{Pu} 119 \mathrm{~d}$ & Up & 1000 & Yes & 50.7 & 1.424 & 1.423 \\
\hline Pu 130 & Down & 1000 & Yes & 14.8 & 0.0065 & 0.0052 \\
\hline Pu 130a & Down & 1000 & Yes & 103.1 & 0.0527 & 0.0514 \\
\hline $\mathrm{Pu} 120$ & Up & 500 & Yes & 47.8 & 7.974 & 7.973 \\
\hline Pu 120a & Up & 500 & Yes & 47.4 & 2.468 & 2.467 \\
\hline Pu 121 & Down & 500 & Yes & 7.4 & 3.427 & 3.426 \\
\hline $\mathrm{Pu} 121 \mathrm{a}$ & Down & 500 & Yes & 7.4 & 0.0078 & 0.0065 \\
\hline $\mathrm{Pu} 122$ & Up & 500 & No & 7.4 & 0.0019 & 0.0006 \\
\hline $\mathrm{Pu} 122 \mathrm{a}$ & Up & 500 & No & 7.4 & 0.0011 & -0.0002 \\
\hline Pu 123 & Down & 500 & No & 7.4 & 0.0008 & 0.0005 \\
\hline $\mathrm{Pu} 123 \mathrm{a}$ & Down & 500 & No & 7.4 & 0.0060 & 0.0047 \\
\hline Pu 124 & Up & 1250 & Yes & 30.3 & 30.06 & 30.06 \\
\hline $\mathrm{Pu} 124 \mathrm{a}$ & Up & 1250 & Yes & 32.9 & 2.924 & 2.923 \\
\hline $\mathrm{Pu} 125$ & Down & 1250 & Yes & 33.7 & 0.0425 & 0.0412 \\
\hline $\mathrm{Pu} 125 \mathrm{a}$ & Down & 1250 & Yes & 28.9 & 0.0336 & 0.0323 \\
\hline $\mathrm{Pu} 126$ & Up & 1250 & No & 35.9 & 0.0413 & 0.0400 \\
\hline $\mathrm{Pu} 126 \mathrm{a}$ & Up & 1250 & No & 36.3 & 0.0275 & 0.0262 \\
\hline Pu 127 & Down & 1250 & No & 31.8 & 0.0697 & 0.0684 \\
\hline $\mathrm{Pu} 127 \mathrm{a}$ & Down & 1250 & No & 32.2 & 2.567 & 2.566 \\
\hline
\end{tabular}

\footnotetext{
(a) Based on a specific activity of $0.096 \mathrm{Ci} / \mathrm{g}$ for the $\mathrm{PuO}_{2}$.

(b) Helium leak rate determined using in-line flowmeter. Standard conditions: $1 \mathrm{~atm}, 25^{\circ} \mathrm{C}$.

(c) The net total is the amount above the containment box background of $0.0013 \mu \mathrm{g}$.
} 

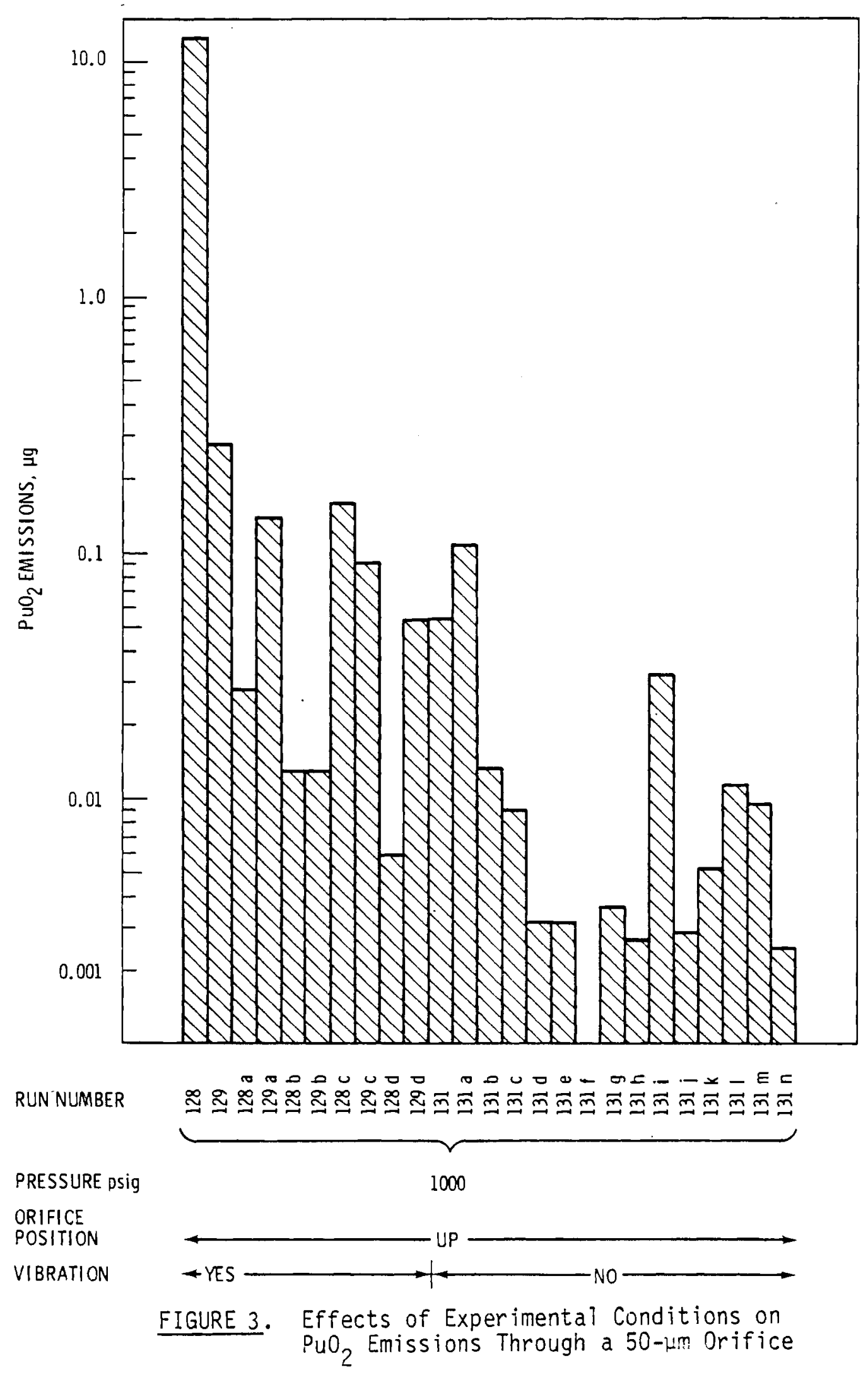
TABLE I I

SUMMARY OF PU0 2 LEAK RATE EXPERIMENTS USING A 50- $4 \mathrm{~m}$ ORIFICE

\begin{tabular}{|c|c|c|c|c|c|c|}
\hline \multirow[b]{2}{*}{$\begin{array}{l}\text { Run } \\
\text { Number }\end{array}$} & \multirow[b]{2}{*}{$\begin{array}{c}\text { Tube } \\
\text { Position }\end{array}$} & \multirow{2}{*}{$\begin{array}{c}\text { Helium } \\
\text { Pressure, } \\
\text { psig }\end{array}$} & \multirow[b]{2}{*}{ Vibration } & \multirow{2}{*}{$\begin{array}{l}\text { Helium } \\
\text { Leak } \\
\text { Rate(b) } \\
\text { scc/sec }\end{array}$} & \multicolumn{2}{|c|}{$\begin{array}{l}\text { Quantity of } \mathrm{Py}_{2} \\
\text { Detected, } \mu \mathrm{q}(\mathrm{a})\end{array}$} \\
\hline & & & & & Total & $\begin{array}{c}\text { Net } \\
\text { Total }(c)\end{array}$ \\
\hline $\mathrm{Pu} 128$ & Up & 1000 & Yes & - & 12.45 & 12.45 \\
\hline $\mathrm{Pu} 128 \mathrm{a}$ & Up & 1000 & Yes & - & 0.0287 & 0.0284 \\
\hline $\mathrm{Pu} 128 \mathrm{~b}$ & Up & 1000 & Yes & - & 0.0132 & 0.0129 \\
\hline Pu $128 \mathrm{c}$ & Up & 1000 & Yes & - & 0.1622 & 0.1619 \\
\hline Pu 128d & Up & 1000 & Yes & - & 0.0063 & .0 .0060 \\
\hline Pu 129 & Up & 1000 & Yes & 9.6 & 0.2905 & 0.2840 \\
\hline Pu $129 a$ & Up & 1000 & Yes & 13.4 & 0.1463 & 0.1398 \\
\hline Pu $129 b$ & Up & 1000 & Yes & 13.0 & 0.0196 & 0.0131 \\
\hline Pu $129 \mathrm{C}$ & Up & 1000 & Yes & 13.7 & 0.0997 & 0.0932 \\
\hline Pu $129 d$ & Up & 1000 & Yes & 14.8 & 0.0600 & 0.0535 \\
\hline $\mathrm{Pu} 131$ & Up & 1000 & No & 14.5 & 0.0562 & 0.0549 \\
\hline Pu 131a & Up & 1000 & No & $13: 7$ & 0.1111 & 0.1098 \\
\hline $\mathrm{Pu} 131 \mathrm{~b}$ & Up & 1000 & No & 21.2 & 0.0149 & 0.0136 \\
\hline Pu 131c & Up & 1000 & No & 16.3 & 0.0105 & 0.0092 \\
\hline Pu 131d & Up & 1000 & No & 14.1 & 0.0046 & 0.0034 \\
\hline $\mathrm{Pu} 131 \mathrm{e}$ & Up & 1000 & No & 13.7 & 0.0046 & 0.0033 \\
\hline Pu $131 \mathrm{f}$ & Up & 1000 & No & 13.0 & 0.0026 & 0.0013 \\
\hline $\mathrm{Pu} 131 \mathrm{~g}$ & Up & 1000 & No & 11.5 & 0.0050 & 0.0037 \\
\hline $\mathrm{Pu} 131 \mathrm{~h}$ & Up & 1000 & No & 13.4 & 0.0040 & 0.0027 \\
\hline $\mathrm{Pu} 131 \mathrm{i}$ & Up & 1000 & No & 12.6 & 0.0342 & 0.0329 \\
\hline Pu $131 \mathrm{j}$ & Up & 1000 & No & 13.4 & 0.0042 & 0.0029 \\
\hline Pu $131 k$ & Up & 1000 & No & 12.6 & 0.0066 & 0.0053 \\
\hline Pu 1311 & Up & 1000 & No & 21.2 & 0.0131 & 0.0118 \\
\hline $\mathrm{Pu} 131 \mathrm{~m}$ & Up & 1000 & No & 20.1 & 0.0112 & 0.0099 \\
\hline $\mathrm{Pu} 131 \mathrm{n}$ & Up & 1000 & No & 19.7 & 0.0038 & 0.0025 \\
\hline
\end{tabular}

(a) Based on a specific activity of $0.096 \mathrm{Ci} / \mathrm{g}$ for the $\mathrm{PuO}_{2}$ powder.

(b) Helium leak rate determined using in-line flowmeter. Standard conditións: 1 atm, $25^{\circ} \mathrm{C}$.

(c) The net total is the amount above the containment box background of $0.0013 \mu \mathrm{g}$ for a ten-minute run. Runs Pu 128 thru Pu 128a are "zero time" runs; Pu 129 thru Pu 129a are 60-min runs. All others are $10-$ min runs. 
provides some information concerning the inherent variability of the experiment. The average emission for these runs is $0.0178 \mu \mathrm{g}$. The actual $\mathrm{PuO}_{2}$ emissions ranged between $0.0013 \mu \mathrm{g}$ and $0.1098 \mu \mathrm{g}$.

- Box Background Determination

The average box background used for the calculations of the net total columns of Tables I through III was obtained by averaging all box background measurements made over the course of the experiment. This average vaitue was chosen since the box background measurements seem to be subject to the same lack of reproducibility as the sample runs. Since the background measurements showed no regular pattern of change, it seemed appropriate to use an average value. The overall average for 22 runs is $0.0013 \mu \mathrm{g}$ with a standard error of $0.0002 \mu \mathrm{g}$.

The collection time for most background runs was $12 \mathrm{~min}$, and the value obtained was subtracted directly from the $10-\min$ sample run values to produce the net total numbers. (For a 10-min run, the collection device is actually operating for $12 \mathrm{~min}$ although the leak tube is pressurized for only $10 \mathrm{~min}$ ). Multiples of these values were then used for background subtraction in the case of extended time runs.

However, a series of background runs (B69 through B77), presented in Table IV, indicates that it may not be valid to use such multiple values for the subtraction. As may be seen by inspection, the average for the $12-$ min runs was $0.0010 \mu \mathrm{g}$ whereas for the 60 -min runs, the average was only 0.0019 . Additionally, in some cases the 12 -min background values were higher than the 60 -min values. For comparison, the overall box background average is $0.0013 \mu \mathrm{g}$.

$\underline{\text { TASK } \mathrm{E}}$-- Investigate $\mathrm{PuO}_{2}$ Leaks Through Simulated Defected Containers

Milestone 1. Fabricate leaky container. Completed.

Milestone 2. Simulant tests. Completed.

Milestone 3. $\mathrm{PuO}_{2}$ test series. Completed.

A statistical analysis of the results of this completed test series is being performed. 
TABLE IV

TIME DEPENDENCE OF BOX BACKGROUND RUNS

\begin{tabular}{ccc}
$\begin{array}{c}\text { Run } \\
\text { Number }\end{array}$ & $\begin{array}{c}\text { Run } \\
\text { Time }(\min )\end{array}$ & $\begin{array}{c}\text { Total Pu02 } \\
\text { Detected }(\mu \mathrm{g})\end{array}$ \\
\hline B69 & 12 & 0.0012 \\
B70 & 60 & 0.0002 \\
B71 & 12 & 0.00004 \\
B72 & 60 & 0.0016 \\
B73 & 12 & 0.0022 \\
B74 & 60 & 0.0034 \\
B75 & 12 & 0.0005 \\
B76 & 60 & 0.0006 \\
B77 & 12 & 0.0010 \\
Average & 12 & 0.0010 \\
Average & 60 & 0.0019
\end{tabular}

TASK F -- Develop analys is methodology

This task objective is to provide a calculational technique supported by the experimental programs of Tasks $B$ through $D$ in order to evaluate the potential release of airborne $\mathrm{PuO}_{2}$ from faulted shipping containers during accidents.

The first part of the calculational technique is a computation method used for gas leaks from the interior sealed container of the Plutonium Air Transport Package (PAT). The TB-1 container of the PAT described in. NUREG-0361 ${ }^{(a)}$ serves as the basic model container for these calculations. A computer code, PAGAN (Particulate and Gas Accident Numerics) has been written, utilizing prescribed temperatures from the air, water vapor and gases from decomposed plastic, to provide the gas leakage history for a container such as the TB-1. Time-dependent mass balances are solved as the gas mixture leaks through a specified leak. The principal output from PAGAN is accumulated gas leakage from the TB-1 during the duration of accident conditions.

(a) Plutonium Air Transportable Package Model PAT-1. Safety Analys is Report, NUREG-0361, U.S. Nuc lear Regulatory Commission, June 1978. 
The second part of the calculational technique is designed to relate powder transmission data to gas leakage. Since the analysis of the data is not complete at this date, no formulas have been finalized to relate powder transmission to gas leakage. These relationships might be incorporated into code PAGAN as planned. However, since the final judgments that relate powder transmission to gas flow might have to rely on paths of reasoning beyond the scope of a computer, the involvement of PAGAN here at this time is uncertain.

The final report on Task $F$ is scheduled for publication in September 1979 as NUREG/CR-0958 PNL-3067: Analysis of Particulate Transmission Through Sma17 Openings Resulting From Container Stresses. 



\section{$\underline{\text { DISTR IBUTION }}$}

No. of

Copies

OFFSITE

A. A. Churm

DOE Patent Division

9800 S. Cass Avenue

Argonne, IL 60439

12 Office of Nuc lear Regulatory Research

Division of Safeguards, Fue 1

Cycle and Environmental

Research

NRC Division of Research

Washington, DC 20555

J. J. Davis

W. Lahs (10)

Frank Swanberg, Jr.

3 NRC Office of Nuclear material

Safety \& Safeguards

Transportation Branch

Washington, DC 20555

Char les E. MacDonald

C. Ross Chappe 11

William H. Lake

2 NRC Division of Technical

Information and Document Control

Washington, DC 20555

Dona Id R. Hopk ins

NRC Division of Standards

Washington, DC 20555
No. of

Copies

OFFSITE

2 DOE Technical Information Center

U.S. Dept. of Energy

P.0. Box 62

Oak Ridge, TN 37830

2 Sandia Laboratories

Albuquerque, NM 87115

John A. Anderson

J. K. Cole

5 Battelle Memorial Institute $505 \mathrm{King}$ Avenue

Columbus, $\mathrm{OH} \quad 43201$

W. J. Madia

E. W. Schmidt

J. D. Yesso (3)

ONSITE

26 Pacific Northwest Laboratory

R. K. Woodruff

J. W. Johnston

J. Mishima

P. C. Owzarski

L. C. Schwendiman (10)

C. E. Elderkin

T. J. Bander

S. L. Sutter

G. B. Long (2)

Publishing Coordination (2)

Technical Information (5)

$B G$ 


\section{.}

